\title{
Knowledge and Attitude of Dental Students and Staffs towards Basic life Support(BLS)
}

\author{
Dr Abdul Saheer P ${ }^{1}$, Shabna V Basheer ${ }^{2}$, Shabna $\mathrm{M}^{2}$, Shahanas Hakkim², \\ Sneha Sanjeev ${ }^{2}$, Sanisha Sadanandan², Dr Shanila Abdul Majid ${ }^{3}$
}

\author{
${ }^{1}$ Assistant professor, Dept of Public Health Dentistry, Al AzharDental College,Thodupuzha, Kerala, India \\ ${ }^{2}$ BDS final Year, Al AzharDental College,Thodupuzha, Kerala, India \\ ${ }^{3}$ Assistant professor, Deptof OMR, Al AzharDental College, Thodupuzha, Kerala, India \\ Corresponding author- Dr Abdul Saheer $\mathrm{P}$ \\ B4/Alsa palm springs, $\mathrm{RC}$ road,Calicut, India \\ Zaheer5475@gmail.com
}

\begin{abstract}
Introduction:The present study was aimed to assess the awareness, knowledge, and attitude towards basic life support (BLS) among the dental students and faculty of Al Azhar dental college.

Materials and Methods: A descriptive study was conducted by using a Questionnaire comprising of 20 questions to collect the data pertaining to awareness and knowledge of $B L S$, attitude towards BLS among the $3^{\text {rd }}$, final year dental students and the faculty members. After excluding the incomplete response sheets which were none in the present study, the data from 212 members were subjected to the analysis. The Main outcome measure was the over all score in the BLS knowledge. Knowledge of BLS was assessed as per the data contained in the Basic life support manual from American Heart Association.
\end{abstract}

Results: Out of 212 members 109 were $3^{\text {rd }}$ year students and 85 were final year students and 18 faculty members. The overall knowledge score was $33.7 \%$. Overall results were poor with less than minimum knowledge on the topic BLS. A score of less than $50 \%$ was evident in the study indicating a poor knowledge of BLS among both the students and the faculty. The range of correct answers were 3-11 among students and 4-6 among the staffs. A significant difference $(p<0.05)$ was observed between students and faculty members.

Conclusion: Present study reports just $33.7 \%$ participants had knowledge regarding BLS necessitates immediate attention of training of dental students and faculties regarding $B L S$.

Keywords-Dentistry, Dental Students, BLS.

\section{INTRODUCTION}

Basic life support (BLS) is a simple life saving protocol following a cardiac arrest. It is an integral part of emergency resuscitative care that aims to retain sufficient ventilation and circulation until the cause of the arrest is detected and eliminated. ${ }^{1}$ As health care professionals, dental practitioners encounter life- threatening medical emergencies. A study by Muller et $\mathrm{al}^{2}$, found that medical emergencies are no rare in dental practise, as about twothirds of dentist faced at least one emergency during the 12 month study period. Early initiation of cardiopulmonary resuscitation by witnesses increases survival after cardiac arrest. In turkey ${ }^{3}$ it is rare that basic life support is initiated by a layperson in the contest of medical emergencies, provision of a competent BLS carries a potential impact on lives. It is recommended that all dental students and staffs, who are exposed to patients, must be trained to offer basic life support. Data from previous studies suggest that more than 3 million sudden cardiac death occur worldwide every year and survival is lower than $8 \% .^{4-6}$ It has also been estimated that by the end of present decade, $60 \%$ of world's heart disease is expected to occur in India and proportionately the incidence and prevalence is expected to rise $^{4}$. It is very important for every medical/dental professionals to know about CPR to save life and improve overall quality of the community health. But low confidence among dental students in performing CPR has been reported from Europe ${ }^{1}$. Different reports have described the knowledge of BSL among health care professionals $^{2-4}$. Chandrasekaran et $\mathrm{al}^{7}{ }^{7}$ evaluated the knowledge of BLS among healthcare students and professionals and found that the study subjects were severely lacking in BLS knowledge. The American Heart Association (AHA) resuscitation guidelines recommend that all under graduated students who are in contact with the patients should have regular resuscitation training ${ }^{3}$. Reddy et $\mathrm{al}^{8}$ assessed the knowledge of BLS among bachelor of dental surgery clinical students, dental interns, postgraduate students and dental faculty in dental school in India. The study concluded that postgraduate students and faculty had significantly poorer knowledge when 
compared to undergraduate students and dental interns. A study by Gonzaga et $\mathrm{al}^{9}$ found that $86 \%$ of the interviewed dentists had received information about CPR; however most of them had not received practical training for cardiopulmonary resuscitation. In recent years several publications have highlighted the deficiencies in CPR quality, both out of hospital and in hospital, which have partly been addressed in the newest BLS guidlines ${ }^{9,10}$.

CPR is controlled by guidelines developed by certain associations such as American heart association ${ }^{11}$ and some other associations in Europe ${ }^{12}$ Singapore $^{13}$ Australia, and New Zealand. ${ }^{14}$ These guidelines are updated regularly to cope with new advances in this field.

In India, the undergraduate curriculum as proposed by the Dental Council of India (DCI) includes medical emergency management under the subjects of general medicine and oral and maxillofacial surgery. ${ }^{15}$ Keeping this in mind, only III, IV, V years (clinical dental students) along with the faculty were included in the study.

Nevertheless, there is no detailed information regarding BLS knowledge and attitude among dental students and staff in dental schools in Kerala.

The aim of the present study is to assess and compare the level of knowledge and attitude toward BLS among bachelor of dental clinical students, staffs at Al- Azhar dental college Thodupuzha.

\section{MATERIALS AND METHOD}

A Cross sectional survey was conducted in Al Azhar dental college (during Feb 2018) among 212participants including dental students and the faculty members to assess the knowledge and attitude towards basic life support. The sample size of 212 which includes 66 males and 146 females. Ethical approval was obtained from the Institutional review board. The sample is divided into two sections $3^{\text {rd }}, 4^{\text {th }}$ year students and faculty which includes 194 students and 18 faculty members. The questionnaire was adapted from the survey used by Shantachandrashekaran7 in a previous study with some modification. Data collection was done by distributing questionnaires among the students and staffs during the clinical and lecture time with prior permission. Questionnaire included 20 closed questions each to evaluate the knowledge and attitude of BLS respectively. Participants had four different options to answer the knowledge questions. For every correct answer a score of 1 was assigned and a score of 0 for every incorrect. The questions were incorporated after going through various literature related to that, which consisted of self-prepared 20 basic questions regarding adult and child BLS, including the experience and attitude of the participants to BLS, theoretical and practical knowledge of the participant to BLS and previous experience and exposure to BLS. The questionnaire prepared was then assessed by carrying out a pilot study among the experienced medical fraternity, and the necessary corrections were made accordingly. The answers were received on the next day of the survey and analyzed. Incomplete responses were excluded from the study. The professional qualifications of the participants were considered. Statistical analysis was performed using SPSS software 20.0.Significance level was kept at $5 \%$.

\section{RESULTS}

Table -1

\begin{tabular}{|c|c|c|c|c|c|}
\hline \multirow[t]{2}{*}{ Sl No. } & \multirow[t]{2}{*}{ Questions } & \multirow[t]{2}{*}{$\underline{\text { Options }}$} & \multicolumn{2}{|c|}{ Clinical students } & \multirow[t]{2}{*}{$\underline{\text { Staffs }}$} \\
\hline & & & $\begin{array}{c}3 \mathrm{rd} \\
\text { YEAR }\end{array}$ & $\begin{array}{c}\text { 4th } \\
\text { YEAR }\end{array}$ & \\
\hline \multirow[t]{2}{*}{1.} & \multirow[t]{2}{*}{ What is the abbreviation of "BLS"? } & Correct & $109(100 \%)$ & $81(95.2 \%)$ & $18(100 \%)$ \\
\hline & & Incorrect & 0 & $4(47 \%)$ & 0 \\
\hline \multirow[t]{2}{*}{2.} & \multirow{2}{*}{$\begin{array}{l}\text { When you find someone unresponsive in } \\
\text { the middle of the road, what will be your } \\
\text { first response? }\end{array}$} & Correct & $48(44.03 \%)$ & $30(35.29 \%)$ & $7(39 \%)$ \\
\hline & & Incorrect & $62(56.81 \%)$ & $55(64.7 \%)$ & $11(61 \%)$ \\
\hline \multirow[t]{2}{*}{3.} & \multirow{2}{*}{$\begin{array}{l}\text { If you confirm somebody is not } \\
\text { responding to you even after shaking } \\
\text { and shouting at him, what will be your } \\
\text { immediate action? }\end{array}$} & Correct & $55(50.4)$ & $33(38.81 \%)$ & $9(50 \%)$ \\
\hline & & Incorrect & $54(49.5 \%)$ & $52(61.11 \%)$ & $9(50 \%)$ \\
\hline \multirow[t]{2}{*}{4.} & \multirow{2}{*}{$\begin{array}{l}\text { What is the location for chest } \\
\text { compression? }\end{array}$} & Correct & $56(51.3 \%)$ & $49(57.6 \%)$ & $7(39 \%)$ \\
\hline & & Incorrect & $53(48.6 \%)$ & $36(42.3 \%)$ & $11(61 \%)$ \\
\hline \multirow[t]{2}{*}{5.} & \multirow{2}{*}{$\begin{array}{l}\text { What is the location for chest } \\
\text { compression in infants? }\end{array}$} & Correct & $34(31.1 \%)$ & $24(28.2 \%)$ & $2(12 \%)$ \\
\hline & & Incorrect & $75(68.8 \%)$ & $61(71.7 \%)$ & $16(88 \%)$ \\
\hline \multirow[t]{2}{*}{6.} & \multirow{2}{*}{$\begin{array}{l}\text { If you do not want to give mouth-to- } \\
\text { mouth CPR, the following can be done } \\
\text { EXCEPT }\end{array}$} & Correct & $25(22.9 \%)$ & $23(27.05 \%)$ & 0 \\
\hline & & Incorrect & $84(77.06 \%)$ & $62(72.9 \%)$ & $18(100 \%)$ \\
\hline
\end{tabular}




\begin{tabular}{|c|c|c|c|c|c|}
\hline \multirow[t]{2}{*}{7.} & \multirow{2}{*}{$\begin{array}{l}\text { How do you give rescue breathing in } \\
\text { infants? }\end{array}$} & Correct & $3(2.7 \%)$ & 0 & 0 \\
\hline & & Incorrect & $106(97.2 \%)$ & $85(100 \%)$ & $18(100 \%)$ \\
\hline \multirow[t]{2}{*}{8.} & \multirow{2}{*}{$\begin{array}{l}\text { Depth of compression in adults during } \\
\text { CPR }\end{array}$} & Correct & $61(55.9 \%)$ & $41(48.2 \%)$ & $6(25 \%)$ \\
\hline & & Incorrect & $48(44.03 \%)$ & $44(51.7 \%)$ & $12(75 \%)$ \\
\hline \multirow[t]{2}{*}{9.} & \multirow{2}{*}{$\begin{array}{l}\text { Depth of compression in Children } \\
\text { during CPR }\end{array}$} & Correct & $26(23.85 \%)$ & $3035.2 \%)$ & $6(34 \%)$ \\
\hline & & Incorrect & $83(76.14 \%)$ & $55(64.5 \%)$ & $12(66 \%)$ \\
\hline \multirow[t]{2}{*}{10.} & \multirow{2}{*}{$\begin{array}{l}\text { Depth of compression in neonates } \\
\text { during CPR }\end{array}$} & Correct & $23(21.01 \%)$ & $13(15.2 \%)$ & $4(29 \%)$ \\
\hline & & Incorrect & $86(78.89 \%)$ & $72(84.7 \%)$ & $14(71 \%)$ \\
\hline \multirow[t]{2}{*}{11.} & \multirow{2}{*}{$\begin{array}{l}\text { Rate of chest compression in adult and } \\
\text { Children during CPR }\end{array}$} & Correct & $18(16.51 \%)$ & $19(22.3 \%)$ & $4(29 \%)$ \\
\hline & & Incorrect & $91(83.9 \%)$ & $66(77.6 \%)$ & $14(71 \%)$ \\
\hline \multirow[t]{2}{*}{12.} & \multirow[t]{2}{*}{ Ratio of CPR, single rescuer in adult is } & Correct & $38(34.8 \%)$ & $28(32.94 \%)$ & $6(34 \%)$ \\
\hline & & Incorrect & $71(65.1 \%)$ & $57(67.05)$ & $12(66 \%)$ \\
\hline \multirow[t]{2}{*}{13.} & \multirow{2}{*}{$\begin{array}{l}\text { In a new born the chest compression and } \\
\text { ventilation ratio is }\end{array}$} & Correct & $21(19.2 \%)$ & $20(23.5 \%)$ & $1(5 \%)$ \\
\hline & & InCorrect & $88(80.7 \%)$ & $65(76.4 \%)$ & $17(95 \%)$ \\
\hline \multirow[t]{2}{*}{14.} & \multirow[t]{2}{*}{ What does abbreviation AED stands for } & Correct & $21(19.2 \%)$ & $18(21.1 \%)$ & 0 \\
\hline & & InCorrect & $88(80.7 \%)$ & $67(78.8 \%)$ & $18(100 \%)$ \\
\hline \multirow[t]{2}{*}{15.} & \multirow[t]{2}{*}{ What does abbreviation EMS stands for? } & Correct & $29(26.6 \%)$ & $19(22.3 \%)$ & $9(50 \%)$ \\
\hline & & InCorrect & $80(73.3 \%)$ & $66(77.6 \%)$ & $9(50 \%)$ \\
\hline \multirow[t]{2}{*}{16.} & \multirow{2}{*}{$\begin{array}{l}\text { If you and your friend are having food in } \\
\text { a canteen and suddenly your friend } \\
\text { starts expressing symptoms of choking, } \\
\text { what will be your first response }\end{array}$} & Correct & $58(53.2 \%)$ & $53(62.3 \%)$ & $1(5 \%)$ \\
\hline & & InCorrect & $51(46.7 \%)$ & $32(37.6 \%)$ & $17(95 \%)$ \\
\hline \multirow[t]{2}{*}{17.} & \multirow{2}{*}{$\begin{array}{l}\text { You are witnessing an infant who } \\
\text { suddenly started choking while he was } \\
\text { playing with the toy, you have } \\
\text { confirmed that he is unable to cry (or) } \\
\text { cough, what will be your first response }\end{array}$} & Correct & $22(20.1 \%)$ & $19(22.35 \%)$ & $3(16 \%)$ \\
\hline & & InCorrect & $87(79.81 \%)$ & $66(77.6 \%)$ & $15(84 \%)$ \\
\hline \multirow[t]{2}{*}{18.} & \multirow{2}{*}{$\begin{array}{l}\text { You are witnessing an adult } \\
\text { unresponsive victim who has been } \\
\text { submerged in fresh water and just } \\
\text { removed from it. He has spontaneous } \\
\text { breathing, but he is unresponsive. What } \\
\text { is the first step? }\end{array}$} & Correct & $15(13.19 \%)$ & $14(16.4 \%)$ & $1(5 \%)$ \\
\hline & & Incorrect & $94(86.2 \%)$ & $71(83.5 \%)$ & $17(95 \%)$ \\
\hline \multirow[t]{2}{*}{19.} & \multirow{2}{*}{$\begin{array}{l}\text { You noticed that your colleague has } \\
\text { suddenly developed slurring of speech } \\
\text { and weakness of right upper limb. } \\
\text { Which one of the following can be } \\
\text { done? }\end{array}$} & Correct & $34(31.19 \%)$ & $29(34.11 \%)$ & $3(16 \%)$ \\
\hline & & Incorrect & $75(68.80 \%)$ & $56(65.88 \%)$ & $15(84)$ \\
\hline \multirow[t]{2}{*}{20.} & \multirow{2}{*}{$\begin{array}{l}\text { A 50-year-old gentleman with } \\
\text { retrosternal chest discomfort, profuse } \\
\text { sweating and vomiting. What is next? }\end{array}$} & Correct & $18(16.51 \%)$ & $12(14.11 \%)$ & $1(5 \%)$ \\
\hline & & Incorrect & $91(83.4 \%)$ & $73(85.88 \%)$ & $17(95 \%)$ \\
\hline
\end{tabular}

Table.2: Descriptive data of questionnaire based on Gender, Academic level and Clinical experience.

\begin{tabular}{|l|l|l|l|l|l|l|l|}
\hline & VARIABLE & NUMBER & $\begin{array}{l}\text { MINIMAL } \\
\text { SCORE }\end{array}$ & $\begin{array}{l}\text { MAXIMAL } \\
\text { SCORE }\end{array}$ & $\begin{array}{l}\text { MEAN } \\
\text { SCORE }\end{array}$ & $\begin{array}{l}\text { STANDARD } \\
\text { DEVIATION }\end{array}$ & P VALUE \\
\hline \multirow{2}{*}{ GENDER } & Male & 66 & 3 & 11 & 6.375 & 1.875 & \multirow{2}{*}{$0.696(t$ t-test) } \\
\cline { 2 - 8 } & Female & 136 & 3 & 11 & 6.286 & 1.884 & \\
\hline $\begin{array}{l}\text { ACADEMIC } \\
\text { LEVEL }\end{array}$ & $\begin{array}{l}\text { Third year } \\
\text { dental } \\
\text { students }\end{array}$ & 109 & 3 & 11 & 4.432 & 1.888 & \\
& & & & & & $0.0002 *$ (Anova \\
\hline
\end{tabular}




\begin{tabular}{|c|c|c|c|c|c|c|c|}
\hline & $\begin{array}{l}\text { Final year } \\
\text { dental } \\
\text { students }\end{array}$ & 85 & 3 & 10 & 4.933 & 1.874 & \multirow[t]{2}{*}{$\begin{array}{l}\text { test) } \\
3^{\text {rd }} \mathrm{yr} \\
4^{\text {th }} \mathrm{yr}(\mathrm{p}=0.134)\end{array}$} \\
\hline & Lecturers & 18 & 3 & 6 & 6.245 & 1.884 & \\
\hline \multirow[t]{2}{*}{$\begin{array}{l}\text { Clinical } \\
\text { experience }\end{array}$} & $\begin{array}{l}\text { Less than } 5 \\
\text { years }\end{array}$ & 13 & 4 & 6 & 5.821 & 1.195 & \multirow[b]{2}{*}{0.406 (t-test) } \\
\hline & $\begin{array}{l}\text { Between } 5 \\
\text { and } 10 \text { years }\end{array}$ & 5 & 3 & 6 & 6.663 & 1.214 & \\
\hline
\end{tabular}

$\mathrm{p}<0.05$ issignificant)

Out of 212 responders 109 were third year dental students, 85 were final year students and 18 faculty members. Ninty four percentage(94\%) of the responders knew the abbreviation of BLS as Basic life support. More than half of the participants $(62 \%)$ failed to insist on looking for safety as the first step in BLS. Majority of the participants $(80 \%)$ failed to insist on activating EMS immediately after confirming the unresponsiveness in an adult.Around $70 \%$ responders did not know that the correct location of chest compression in an infant was one finger breadth just below the nipple line. Majority $(77.5 \%)$ the responders did not know alternative techniques of resuscitation when mouth-to-mouth ventilation was not opted. Almost all of the participants $(99.5 \%)$ of the responders failed to select mouth-to-mouth and nose technique as the rescue breathing for infants. Forty nine percentage participants did not know that the depth of chest compression in an adult was 1.5 to 2 inches. Lack of knowledge regarding the depth of chest compression in a child was one-third to onehalf the depth of the chest was $72 \%$. Eighty percentage did not know that the chest compression in an infant was onethird to one-half the depth of the chest. Only $18 \%$ of the responders answered the rate of chest compression as 100/minute in adults and children CPR.Only 33\% of the responders had correctly answered that the compression ventilation ratio in a child and adult single rescuer CPR was 30:2. Only $20 \%$ knew that the ratio of compression ventilation in a new born was 3:1. Responders did not know that the abbreviation of AED was 'automated external defibrillator' was $80 \%$ and only $25 \%$ cent knew that the abbreviation of EMS was 'Emergency Medical Service'. Fourty five $(45 \%) \%$ did not know that the first step in helping a suspected foreign body obstruction victim is to confirm the severity of obstruction by talking to him. Only $31.5 \%$ of the responders did not know the early signs of stroke and only $14 \%$ per cent knew how to recognise and help a patient with acute coronary syndrome.The overall knowledge score was $33.7 \%$. No participants had complete knowledge on BLS.

Table 2 explains response comparison based on Gender, Academic level and clinical experience. Males and females had almost equal level of knowledge regarding BLS. (Mean value $6.3 \& 6.2$ each). Third year students showed a mean value of 4.4 ,final years with 4.9 and staff being highest value 6.9. The difference was statistically significant. $(\mathrm{p}<0.05)$. Staff $\mathrm{s}$ with less than and more than 5 years of experience did not show any much difference in the knowledge.(5.82\&6.63)

\section{DISCUSSION}

The present study assessed knowledge of students and faculty regarding BLS in a private dental college in southern Kerala.The study showed that dental students and faculty in the study group were lacking in the awareness of BLS. Awareness of BLS was poor in all the students. This study emphasized the cognitive approach to the general perception and skills of Basic Life Support, early recognition of stroke and acute coronary syndrome. The practising and teaching doctors in this study scored less this explained why many dental doctors were not good in carrying out effective CPR. ${ }^{16} \mathrm{It}$ is now essential to standardise training in advanced life support and make it a mandatory component of all dental school undergraduate curricula. It is also equally important that teachers, school children, public and all lay persons from the community be taught the facts of basic life support and first. Study population with positive knowledge score was 33.7\%.A similar finding was observed in studies conducted by Shanthachandrashekaret $\mathrm{al}^{7}$ and inadequate knowledge on BLS. A different and positive finding was reported by the study conducted by Malford TPet al. ${ }^{17}$ The range of correct answers given by students was 6-11, whereas it is surprising and alarming that the same with faculties were in range of 4-6. Although the mean knowledge score is significantly differ from the student's, the negligible number of staff population must not be a representative population. The present study report that the students have a negative attitude ie mere $33.7 \%$ responded positively to the attitude and practical based questions. Lack of professional training of BLS was regarded as the most common hindering factor responsible for poor BLS knowledge by dental students. ${ }^{18-20}$ Baduni $\mathrm{N}$ et $\mathrm{al}^{21}$ reported score of $9.2 \pm 1.2$ among dental practitioners which is better than the present study where mean score was 6.5. The majority of the study participants of the present study reported that BLS training should be a part of the dental curriculum and raised the point that there was no professional training available. A recommendation to 
develop undergraduate health courses and strategies to teach professionals and students appropriate theoretical as well as practical knowledge, behaviour and attitudes when facing life-threatening emergencies was reported in a study conducted by Carvalhoet $\mathrm{al}^{22}$. Studies conducted by Elanchezhiyan et $\mathrm{al}^{23}$ Reddy et $\mathrm{al}^{8}$,Baduni et $\mathrm{al}^{21}$ and Ehigiator et $\mathrm{al}^{24}$ reported that a considerable portion of the study population in the respective studies had knowledge scores below average and recommended that proper strategies should be devised to bridge the lacunae in the knowledge.

\section{CONCLUSION}

The findings of the present study demonstrates poor knowledge (33.7\%) among dental students regarding BLS and showed the urgent need for continuous refreshing courses for this critical topic.

\section{ACKNOWLEDGMENT}

Authors would like to acknowledge all the survey participants.

\section{LIMITATIONS AND RECOMMENDATIONS}

This study has some limitations that should be taken into consideration. One possible limitation is the likelihood of selection bias given that dental students who chose to participate in the survey may be keener interested or concerned with CPR than those who did not participate.

Therefore, the results are likely not generalizable to nonrespondents. In addition, a general limiting characteristic of self-reporting survey is the probability of socially acceptable responding, Nonetheless, despite these limitations, the study provides some important information about Al Azhardental students, Kerala knowledge and attitude regarding principles of BLS.

\section{REFERENCES}

[1] Berg Robert A, Hemphill Robin, Abella Benjamin S, AufderheideTom P, Cave Diana M, Hazinski Mary Fran,et al. Part 5: Adult basic support 2010 American Heart Association guidelines for cardiopulmonary resuscitation and emergency cardiovascular care. Circulation 2010; 122(18 suppl 3): S685- 7-05.

[2] Muller MP, Hansel M, Stehr SN, Weber S, Koch T. A state- wide survey of medical emergency management in dental practises: incidence of emergencies and training experience. Emerge Med J 2008;25(5):296- 300

[3] SuleOzbligin, MertAkan and BaharKuvaki: Evaluation of public awareness, knowledge and attitude about cardiopulmonary resuscitation: reports of izmir.
[4] Boriani G, Valzania C, Diemberger I, Biffi M, Martignani C, Bertini M, et al. Potential of non- ant arrhythmic drugs to provide an innovative upstream approach to the pharmacological prevention of sudden cardiac death. Expert opinion on investigational drugs.2007: 16(5): 605- 23.

[5] Josephson ME, Wellens HJJ. Implantable defibrillators and sudden cardiac death .Circulation.2004; 2685- 91

[6] Sasson C, Rogers MAM, Dah J, Kellermann AL, Predictors of survival from out- of- hospital cardiac arrest: a systematic review and meta- analysis. Circulation. Cardiovascular quality and outcomes 2010; 63- 81.

[7] Chandrasekaran S, Kumar S, Bhat SA et al : "Awareness of basic life support among medical, dental, nursing students \&doctors".Indian J Anaesth 2010; 54 : 121-6 3. S Raghavan, H Schneider, WGJ Kloeck: "Basic resuscitation-knowledge

[8] Sahithi Reddy, DolarDoshi, Padma Reddy, Suhas Kulkarni, Srikanth Reddy. Awareness of basic life support among staff and students in a dental school. J Contemp Dent Pract 2013;14(3):5511-7.

[9] Gonzaga Heron Fernando de Sousa, Chaves Marcelo es de, almeidaosleiPaes de. Evaluation of knowledge and experience of dentists of SaoPaulo State, Brazil about cardiopulmonary resuscitation. Braz Dent $\mathrm{J}$ 2003;14(3):220-2

[10] Mohan V, Deepa R, Rani SS, Premalatha G. Prevalence of coronary artery disease and its relationship to lipids in a selected population in South India. J Am CollCardiol. 2001 ; 38:682-7.

[11] Freund Y, Duchateau FX, Baker EC, Goulet H, Carreira S, Schmidt M, et al. Self- perception of knowledge and confidence in performing basic life support among medical students. Eur J Emerg Med. 2013;20:145- 6 .

[12]Florian Laurent, Pascal Augustin, Cathy Nabet, Sophie Ackers, DaamianZamaroczy, Louis Maman. Managing a cardiac arrest ; evaluation of final year predectoral dental students. J Dent Educ 2009;73(2): 211-7.

[13]Lim SH. Basic cardiac life support: 2011 Singapore guidelines. Singapore Med J. 2011;52:53842.[PubMed]

[14] Australian Resuscitation Council; New Zealand Resuscitation Council. Basic life support: Cardiopulmonary resuscitation. ARC and NZRC Guideline 2010. Emerg Med Australas. 2011;23:25960.

[15] Dental council of India. [homepage on the internet]. BDS course syllabus. [Cited 2007 May 10]. Available from: http:// www.dciindia.org/BDSsyl.pdf 
[16] Shrestha Roshana, Batajoo KH, Piryani RM, Sharma MW. Basic life support: knowledge and attitude ofr medical or paramedical professionals. Wold J Emerg ,ed 2012;3(2):141-5.

[17] Tyson Pillow Malford, Donald Stader, Mattthew Nguyen, Dazhe McArthur, RobertMcArthur, Shkelzen H oxhaj. Perceptions of basic, advanced, and pediatric life support training in a united states medical school. J Emerg Med 2014;46(5):695-700.

[18] Spencer B, Chacko J, Sallee D. American Heart Association. The 2010 American Heart Association guidelines for cardiopulmonary resuscitation and emergency cardiac care: An overview of the changes to pediatric basic and advanced life support. Crit Care NursClin North Am. 2011;23:303-10. [PubMed]

[19] Sandroni C, Nolan J. European Resuscitation Council. ERC 2010 guidelines for adult and pediatric resuscitation: Summary of major changes. Minerva Anestesiol. 2011;77:220-6. [PubMed]

[20] WedgoTsegaye, Million Tesfaye and MengistuAlemu. Knowledge, attitude and practice of cardiopulmonary resuscitation and associated factors in Ethiopian university medical students; Jimma university, College of health sciences Ethiopia.

[21] Baduni N, Prakash P, Srivastava D, Sanwal M, Singh B. Awareness of basic life support among dental practitioners. Natl J Maxillofac Surg. 2014;5(1):1922.

[22] Carvalho RM, Costa LR, Marcelo VC. Brazilian dental student's perceptions about medical emergencies: a qualitative exploratory study. J Dent Educ. 2008;72(11):1343-9.

[23] Elanchezhiyan S, Elavarasu S, Vennila K, Renukadevi R, Mahabob MN, Sentilkumar B, et al. Awareness of dental office medical emergencies among dental interns in southern India: An Analytical study. J Dent Educ. 2013;77(3):364-9.

[24] Ehigiator O, Ehizele A, Ugbodaga P. Assessment of a group of Nigerian dental student's education on medical emergencies. Ann Med Health Sci Res. 2014;4(2):248-52. 